\title{
A REVIEW OF 138 CASES OF CLOSURE OF TUBERCULOUS LUNG CAVITIES UNDER CHEMOTHERAPY*
}

\author{
BY \\ J. D. ROSS AND D. T. KAY \\ From the Department of Tuberculosis and Diseases of the Chest, University of Edinburgh
}

(RECEIVED FOR PUBLICATION OCTOBER 14, 1955)

It is widely recognized that closure of tuberculous lung cavities may be achieved in the course of chemotherapy. More will be said later in this paper concerning the frequency of this occurrence. Once cavity closure has been obtained, the clinician is faced with a problem of management. If he accepts the widely held clinical impression that cavity closure under chemotherapy is an insecure state with a high likelihood of relapse, he will recommend resection or collapse therapy. On the other hand, he may place his faith in a conservative policy without resort to surgical or mechanical procedures. One of the objects of the study to be described was to compare the results of these two broadly differing lines of management-surgery and conservatism.

\section{MeTHOD OF STUdY}

The records of all patients discharged from three units for adult cases of pulmonary tuberculosis were examined for the period June, 1952, to December, 1954. Of a total of 745 , in 138 it was judged that all lung cavities had closed while the patients received no other treatment than chemotherapy and the sanatorium régime. All these patients had had unequivocal cavitation distinguishable on an ordinary radiograph. Cases in which cavitation was merely suspect were not included. A decision as to whether a cavity was closed was based on a consideration of all available radiographs and these included tomograms in nearly all cases. The date of the first radiograph showing no evident cavity was taken as the date of closure. All patients in the series became bacteriologically negative by cultural methods while under treatment. The subsequent management of these 138 patients is shown in Table I. Forty-one were still receiving drugs at the time of the last observation; 97 had completed their period of drug treatment. Ninetytwo had no other treatment than chemotherapy;

* Based upon a paper read by J. D. Ross to the Thoracic Society on July 1, 1955. these constituted the conservatively treated group. Forty-six were submitted to additional measures after cavities had closed: major surgery, usually resection, in the case of 26 , and minor collapse procedures, principally pneumoperitoneum, in the remaining 20. The experience of these groups was assessed in terms of the number of "relapses" which occurred after cessation of treatment. "Relapse" was defined as radiological deterioration (which might include reopening of a cavity but not necessarily so) or the reappearance of tubercle bacilli in the sputum, or both these events. The date of the last available radiograph before June 1, 1955, has been used in assessing the period of follow-up credited to each patient, provided earlier relapse had not occurred.

TABLE I

SUBSEQUENT MANAGEMENT OF 138 PATIENTS WITH CAVITIES CLOSING ON CHEMOTHERAPY

\begin{tabular}{|c|c|c|c|c|c|c|c|}
\hline & \multirow{3}{*}{$\begin{array}{c}\text { Chemo- } \\
\text { therapy } \\
\text { Only }\end{array}$} & \multicolumn{5}{|c|}{ Chemotherapy + Surgery } & \multirow{3}{*}{ Total } \\
\hline & & \multicolumn{3}{|c|}{ Minor } & \multicolumn{2}{|c|}{ Major } & \\
\hline & & P.P. & $\begin{array}{l}\text { P.P. }+ \\
\text { Phrenic }\end{array}$ & A.P. & $\begin{array}{c}\text { Resec- } \\
\text { tion }\end{array}$ & $\begin{array}{l}\text { Thorac- } \\
\text { oplasty }\end{array}$ & \\
\hline $\begin{array}{l}\text { Drugs } \\
\text { stopped } \\
\text { On drugs at } \\
\text { last ob- } \\
\text { servation }\end{array}$ & 37 & 14 & 0 & 0 & 18 & 0 & $\begin{array}{l}97 \\
41\end{array}$ \\
\hline \multirow[t]{3}{*}{ Total } & 92 & 16 & 3 & 1 & 20 & 6 & 138 \\
\hline & & \multicolumn{3}{|c|}{20} & \multicolumn{2}{|r|}{26} & \\
\hline & & \multicolumn{5}{|c|}{46} & \\
\hline
\end{tabular}

RELAPSE EXPERIENCE OF CONSERVATIVELY AND Surgically Treated Groups

Conservatively Treated Group.-The followup of the 92 patients ( 49 men, 43 women) treated by chemotherapy alone is shown in modified lifetable form in Table II. In this table, the starting point of observation is the time of the first radiograph interpreted as showing no evidence of cavitation. The third column indicates the number 
TABLE II

FOLLOW-UP OF 92 PATIENTS WITH CAVITIES CLOSING UNDER CHEMOTHERAPY AND TREATED CONSERVATIVELY

\begin{tabular}{|c|c|c|c|c|c|c|c|}
\hline $\begin{array}{c}\text { Observation } \\
\text { Period since } \\
\text { Cavity Closure } \\
\text { (Mth.) } \\
\text { X }\end{array}$ & $\begin{array}{c}\text { Number } \\
\text { Entering } \\
\text { Period } \\
\text { Ox }\end{array}$ & $\begin{array}{c}\begin{array}{c}\text { Number } \\
\text { Relapsing }\end{array} \\
\Gamma x\end{array}$ & $\begin{array}{c}\begin{array}{c}\text { Having } \\
\text { Latest } \\
\text { Observation }\end{array} \\
\text { Wx }\end{array}$ & $\begin{array}{c}\text { Average } \\
\text { Persons at } \\
\text { Risk during } \\
\text { Period } \\
O x-\frac{W x}{2}\end{array}$ & $\begin{array}{l}\begin{array}{c}\text { Probability } \\
\text { of Relapse }\end{array} \\
\frac{\Gamma x}{O x-\frac{W x}{2}}\end{array}$ & $\begin{array}{l}\text { Probability of } \\
\text { Not Relapsing }\end{array}$ & $\begin{array}{l}\% \text { Cumulative } \\
\text { Probability of } \\
\text { No Relapse } \\
\text { before Period }\end{array}$ \\
\hline $\begin{array}{c}0- \\
3- \\
6- \\
9- \\
12- \\
15- \\
18- \\
21- \\
24- \\
30- \\
36-\end{array}$ & $\begin{array}{l}92 \\
92 \\
90 \\
80 \\
64 \\
51 \\
45 \\
32 \\
24 \\
12 \\
4\end{array}$ & $\begin{array}{l}0 \\
0 \\
1 \\
1 \\
1 \\
0 \\
0 \\
0 \\
1 \\
0\end{array}$ & $\begin{array}{r}0 \\
2 \\
9 \\
15 \\
12 \\
6 \\
13 \\
8 \\
11 \\
8\end{array}$ & $\begin{array}{l}92 \\
91 \\
85 \cdot 5 \\
72.5 \\
58 \\
48 \\
38.5 \\
28 \\
18 \cdot 5 \\
8\end{array}$ & $\begin{array}{c}0 \\
0 \\
0.0117 \\
0.0138 \\
0.0172 \\
0 \\
0 \\
0 \\
0.0541 \\
0\end{array}$ & $\begin{array}{c}1.0 \\
1.0 \\
0.9883 \\
0.9862 \\
0.9828 \\
1.0 \\
1.0 \\
1.0 \\
0.9459 \\
1.0\end{array}$ & $\begin{array}{l}100 \\
100 \\
100 \\
99 \\
97 \cdot 5 \\
96 \\
96 \\
96 \\
96 \\
90 \cdot 5 \\
90 \cdot 5\end{array}$ \\
\hline
\end{tabular}

of relapses at different periods after the beginning of observation. There have been four relapses, one occurring as late as the twenty-fifth month. The fourth column shows the number of patients withdrawn from analysis in each time period because they have reached their last available radiograph and can be credited with no further experience. They include one patient who died as a result of coronary thrombosis with no deterioration in his tuberculous condition. If we assume that those whose observations have been short will have a similar later experience to patients observed for longer periods (and there is no reason to regard them as a biased group) the expected percentage of patients remaining well, free from relapse, at different periods of time after cavity closure, can be calculated. The result of the calculation is given in the last column, from which it can be seen that at two years one would expect $96 \%$ of patients to have remained well ( $4 \%$ having relapsed).

COMPARISON OF SURgICAL AND CONSERVATIVE GrouPs.-This comparison is shown in Table III, in which observation has been dated not from cavity closure but from cessation of chemotherapy. This course was adopted because no cases relapsed while on drug therapy, and our experience in general

TABLE III

RELAPSE EXPERIENCE AFTER STOPPING DRUGS IN 97 PATIENTS WITH CAVITIES CLOSING UNDER CHEMOTHERAPY

\begin{tabular}{|c|c|c|c|c|c|}
\hline \multirow{2}{*}{$\begin{array}{l}\text { Type of } \\
\text { Treatment }\end{array}$} & \multirow{2}{*}{$\begin{array}{c}\text { Chemo- } \\
\text { therapy } \\
\text { Only }\end{array}$} & \multicolumn{3}{|c|}{ Chemotherapy + Surgery } & \multirow{2}{*}{ Total } \\
\hline & & Minor & Major & $\begin{array}{c}\text { All } \\
\text { Forms }\end{array}$ & \\
\hline No. of cases $\ldots$ & 55 & 18 & 24 & 42 & 97 \\
\hline $\begin{array}{l}\text { drugs stopped ... } \\
\text { Relapses }\end{array}$ & $\frac{820 \cdot 5}{4}$ & $\begin{array}{r}312 \\
1\end{array}$ & $\begin{array}{r}416 \\
1\end{array}$ & $\begin{array}{r}728 \\
2\end{array}$ & $\underset{6}{1548 \cdot 5}$ \\
\hline $\begin{array}{c}\text { Relapse rate per } 100 \\
\text { person/years }\end{array}$ & 5.9 & 3.8 & 2.9 & $3 \cdot 3$ & 4.7 \\
\hline
\end{tabular}

suggests that deterioration of lung tuberculosis is $\vec{z}$ a rare occurrence so long as a patient is receiving a satisfactory combination of those anti-tuberculous $\frac{\hat{\partial}}{\partial}$ drugs to which the organism is sensitive. Exclusion $\vec{\theta}$ of the patients still on drugs at the time of the last oु observation leaves a total number for analysis of 97.

Two relapses have been observed in the surgical group, one in a thoracoplasty case and the other in a patient receiving pneumoperitoneum. These two relapses among the 42 "surgical" patients compare with four relapses in the 55 conservatively $\cong$ treated patients. By aggregating the number of $\overrightarrow{\overrightarrow{0}}$ months for which each patient had been observed since drugs were stopped a total person-months experience was obtained for each group, allowing the calculation of relapse rates. The surgical group experienced a $3.3 \%$ annual relapse rate compared with $5.9 \%$ for the conservatively treated group. This difference is based on a small total number of relapses and is of a degree not statistically significant.

A comparison of the groups in respect of relapse experience has little meaning without knowledge of how the groups compared as regards other measur- $\frac{9}{2}$ able characteristics.

\section{Comparison of Characteristics of Treatment GrouPS}

Original Extent of Disease.-Each case was $\stackrel{N}{\circ}$ classified according to the extent of disease shown $\omega$ in the radiograph immediately before chemotherapy was begun. A case was classified as of minimalco extent when the disease shadowing involved an area $\mathbb{D}$ of lung equivalent to not more than one lung zone $?$ irrespective of the actual distribution of the lesions $\frac{T}{T}$ in the lung fields. Where the amount of lung $\underset{\mathbb{D}}{\stackrel{+}{*}}$ involved was equivalent to two or three lung zones, $\stackrel{\odot}{\stackrel{\oplus}{\odot}}$ the case was designated moderately advanced. Far $\stackrel{\square}{\square}$ advanced disease implied more than three lung zones $\overrightarrow{2}$ involved. 
As shown in Fig. 1, the surgical group contained a higher proportion of minimal cases than did the conservative group: $33 \%$ of the total as against $19 \%$. Particularly was this so among the group receiving major surgery, in which $46 \%$ of the

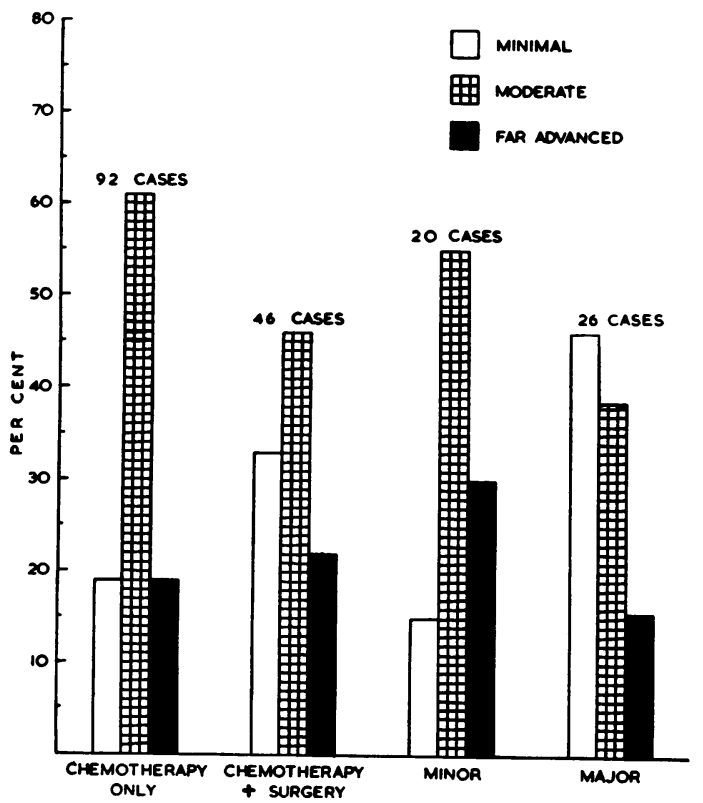

FIG. 1.-Distribution of patients by extent of disease.

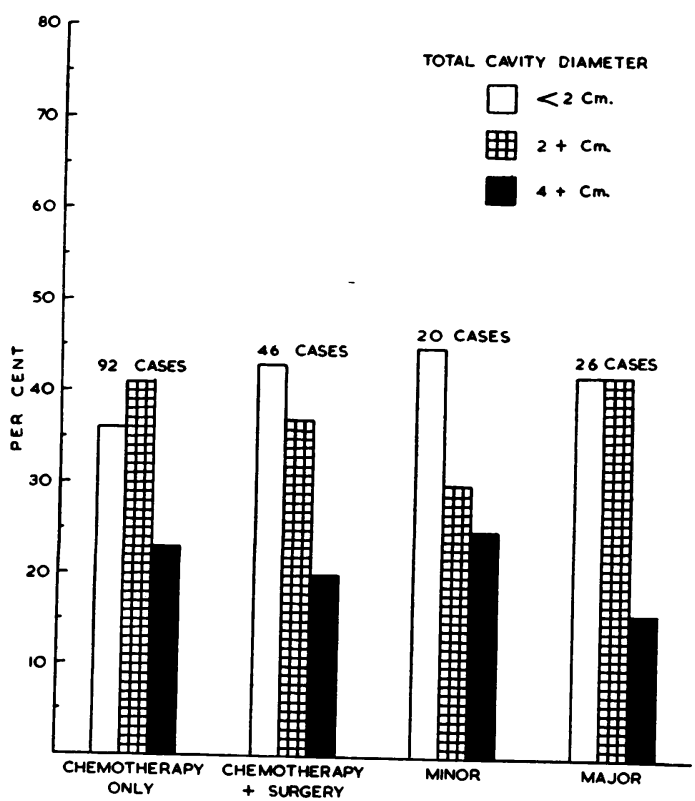

FIG. 2.-Distribution of patients by extent of original cavitation. patients were classified as minimal. The figures indicate a tendency to advise major surgery, in particular resection, where the disease process was relatively localized. If extent of original disease is of prognostic significance-and there are many studies to indicate that it is-then the surgical group have an advantage in this regard.

EXtent of ORIGinal Cavitation.-The extent of cavitation in the pre-chemotherapy radiograph was recorded as the sum of the diameters of all cavities. The data are summarized in Fig. 2, which shows that the groups are roughly similar, with a tendency for less extensive cavitation in the surgical group.

Residual Foci after Cavity Closure.-The largest residual focus in the area of former cavitation was measured, using for the purpose either the tomograms taken to confirm cavity closure or the radiograph taken within three months of cavity closure which showed the greatest definition of lesions. In some cases the focus measured appeared to be a single lump, though in others the "focus" was more probably an aggregate of several smaller foci which had fused. The patients were grouped into three categories, according to the diameter of the largest residual focus-less than $1 \mathrm{~cm} ., 1$ to $2 \mathrm{~cm}$., and $2 \mathrm{~cm}$. or more (Fig. 3). The surgical group had a higher proportion of residual lumps. greater than $2 \mathrm{~cm}$. in diameter. This difference was

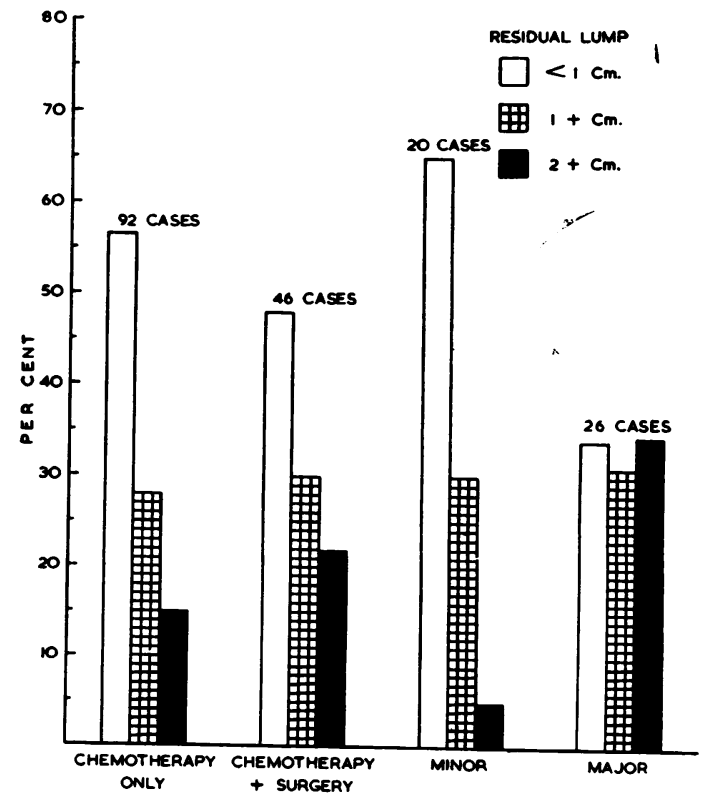

Fig. 3.-Distribution of patients according to size of largest residual lump after cavity closure. 
due to the high number of large lumps among patients receiving major surgery.

In view of this finding, the material was examined to ascertain the relationship, if any, between size of residual lump and likelihood of relapse (Table IV). In this table, patients still on chemotherapy are again omitted, and so also those treated by resection, as their obvious " lumps" were removed surgically. Among the 18 resection cases in which chemotherapy had been terminated, no relapses have occurred. Furthermore, this resection group contained a higher proportion of large residual lumps than did any other group. Their retention in Table IV would therefore have resulted in lower

TABLE IV

RELAPSES RELATED TO SIZE OF LARGEST RESIDUAL LUMP

\begin{tabular}{c|c|c|c|c}
\hline $\begin{array}{c}\text { Size of } \\
\text { Lump } \\
\text { (cm.) }\end{array}$ & $\begin{array}{c}\text { No. of } \\
\text { Patients }\end{array}$ & $\begin{array}{c}\text { Person } \\
\text { months } \\
\text { Observation }\end{array}$ & $\begin{array}{c}\text { No. of } \\
\text { Relapses }\end{array}$ & $\begin{array}{c}\text { Relapse } \\
\text { Rate per } \\
100 \text { P Yr. }\end{array}$ \\
\hline$<1$ & 46 & 707 & 4 & 6.78 \\
$1+$ & 23 & $388 \cdot 5$ & 1 & 3.09 \\
2 & 10 & 157 & 1 & 7.64 \\
\hline Total & 79 & $1252 \cdot 5$ & 6 & 5.75 \\
\hline
\end{tabular}

(Omitting cases still on chemotherapy and cases submitted to resection.)

relapse rates than those shown for all groups but particularly for the group with lumps $2 \mathrm{~cm}$. or more after cavity closure. Even as it stands, however, Table IV fails to show any clear relationship between the size of residual lump and the likelihood of relapse. The figures are, of course, small and do not permit any definite conclusion, but to date the majority of relapses have occurred among patients with small residual foci less than $1 \mathrm{~cm}$. in diameter.

The possibility remained that a relationship between size of residual lump and relapse was being masked by some other factor, perhaps the most likely possibility being the duration of chemotherapy. It was thought possible, indeed probable, that cases with large lumps not submitted to resection would on average receive longer chemotherapy

\section{TABLE V}

SIZE OF LARGEST RESIDUAL LUMP RELATED TO DURATION OF CHEMOTHERAPY AFTER CAVITY CLOSURE*

\begin{tabular}{|c|c|c|c|c|c|}
\hline \multirow{2}{*}{\multicolumn{2}{|c|}{$\begin{array}{l}\text { Duration of Drugs } \\
\text { after Cavity Closure }\end{array}$}} & \multicolumn{3}{|c|}{$\begin{array}{c}\text { Diameter of } \\
\text { Largest Residual Lump in } \mathrm{cm} .\end{array}$} & \multirow[t]{2}{*}{ Total } \\
\hline & & $<1$ & $1+$ & $2+$ & \\
\hline \multirow{2}{*}{$\begin{array}{lll}<4 & \text { months } \\
4-8 \quad, \quad & \cdots \\
8+ & " & \\
& & \text { Total }\end{array}$} & $\begin{array}{l}\cdots \\
\cdots \\
\cdots\end{array}$ & $\begin{array}{l}11 \\
16 \\
19\end{array}$ & $\begin{array}{r}3 \\
8 \\
12\end{array}$ & $\begin{array}{l}5 \\
3 \\
2\end{array}$ & $\begin{array}{l}19 \\
27 \\
33\end{array}$ \\
\hline & $\ldots$ & 46 & 23 & 10 & 79 \\
\hline
\end{tabular}

* Resection cases and cases still on drugs excluded. than did patients with smaller residual foci. Table $\stackrel{\overrightarrow{\vec{S}}}{\stackrel{\vec{D}}{+}}$ $\mathrm{V}$ demonstrates the opposite trend, however. Half $\mathrm{O}$ of the patients with large foci (greater than $2 \mathrm{~cm}$.) received less than four months' chemotherapy after cavity closure, while less than a fourth of the group with small foci (less than $1 \mathrm{~cm}$.) received such a is short period; a considerably higher proportion of $\vec{\Omega}$ patients with small foci received long periods of chemotherapy after cavity closure. It is obvious $\vec{\omega}$ that the duration of chemotherapy did not therefore mask a relationship between size of residual foci $\overrightarrow{\vec{x}}$ and likelihood of relapse, and in this study we have been unable to demonstrate any such relationship.

DURATION OF Chemotherapy after CAVITY Closure.-Fig. 4 shows that in general the conservatively treated group received longer chemotherapy after cavity closure than did the surgical group. The relationship between duration of $\frac{\widehat{S}}{\mathrm{~S}}$ chemotherapy and relapse experience was therefore examined (Table VI). Considering all cases (surgical and conservative) it is seen that no relapses have occurred among the 39 patients who received eight months or more of chemotherapy after radiological cavity closure. The group receiving less than four months' chemotherapy experienced five relapses with an annual relapse rate of $11.6 \%$ and patients receiving four to eight months' chemotherapy had one relapse and an annual relapse rate of $1.9 \%$. The differences between "observed"

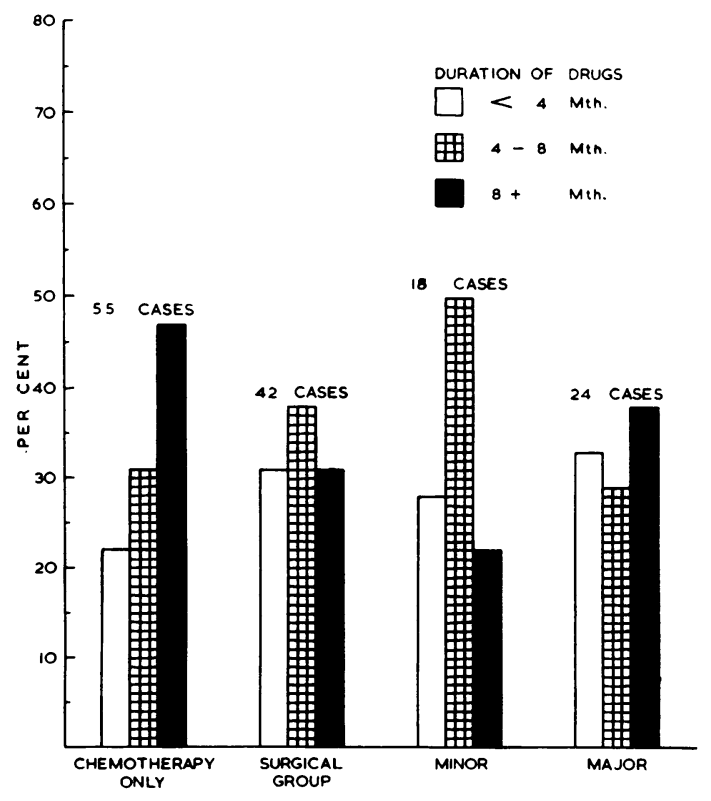

FIG. 4.-Graph showing duration of chemotherapy after cavity closure related to type of treatment. 
and "expected" relapses in the chemotherapy groups are larger than would be expected by chance, and indicate a real relationship between the duration of chemotherapy after cavity closure and the incidence of relapse.

\section{Subsequent Course of Relapsed Patients}

Some details concerning the patients who relapsed are shown in Table VII. The longest period of chemotherapy after cavity closure was six months. With subsequent treatment all six patients who relapsed show no present evidence of cavitation and five were working at the time of the last review. In four cases the " relapse" included reopening of a cavity. In three of these, cavities were closed again with drugs alone (though a thoracoplasty was subsequently performed in one instance), and in the fourth closure was aided by a pneumoperitoneum.

\section{Frequency of Cavity Closure with CHEMOTHERAPY}

The response to chemotherapy of all cavitated cases from one of the units was analysed in modified life-table form (Table VIII). Of 115 patients with lung cavities at the beginning of chemotherapy, in
58 all the cavities were closed while on chemotherapy alone, an observed cavity closure rate of $50 \%$. A progressive increase in the percentage of successful closures was observed with continued drug treatment for eight months.

Many of the patients received some other form of treatment-surgery or collapse-after a short preliminary period of chemotherapy while cavitation was still present, and in other instances drugs were stopped for one reason or another. These patients are shown in the withdrawal column. It is certain that in a proportion of them the cavities would have closed on drugs alone had they been given the opportunity. Assuming that they do not constitute a biased group, i.e., that if maintained on drugs alone they would have had a similar experience to those patients remaining in the analysis, the "expected" percentage of patients with unclosed cavities can be estimated for different durations of drug treatment (last column). This calculation shows an expected percentage of cavity closure of $100-21$, i.e., $79 \%$, after eight months' chemotherapy.

In fact, the " withdrawals" possibly do represent a biased group, as there might be an inclination for the clinician to resort to early surgery if he considered cavity closure improbable on chemotherapy

TABLE VI

INCIDENCE OF RELAPSE RELATED TO DURATION OF CHEMOTHERAPY AFTER CAVITY CLOSURE

\begin{tabular}{|c|c|c|c|c|c|c|c|c|c|}
\hline \multirow[b]{2}{*}{$\begin{array}{c}\text { Duration of drugs in months after } \\
\text { cavity closure } \ldots\end{array}$} & \multicolumn{3}{|c|}{ Surgical Group } & \multicolumn{3}{|c|}{ Conservative Group } & \multicolumn{3}{|c|}{ Combined Groups } \\
\hline & $<4$ & $4-8$ & $8+$ & $<4$ & $4-8$ & $8+$ & $<4$ & $4-8$ & $8+$ \\
\hline $\begin{array}{l}\text { Number of cases } \ldots \\
\text { Person-months observed }\end{array}$ & 13 & 16 & 13 & 12 & 17 & 26 & 25 & 33 & 39 \\
\hline 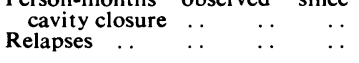 & $\underset{2}{291 \cdot 5}$ & $\begin{array}{r}311 \\
0\end{array}$ & $\underset{0}{125 \cdot 5}$ & $\begin{array}{r}226 \\
3\end{array}$ & $\frac{327 \cdot 5}{1}$ & $\begin{array}{r}267 \\
0\end{array}$ & $\begin{array}{c}517 \cdot 5 \\
5\end{array}$ & $\begin{array}{c}638 \cdot 5 \\
1\end{array}$ & $\begin{array}{c}392 \cdot 5 \\
0 \\
0\end{array}$ \\
\hline \multirow[t]{2}{*}{ Relapse rate per 100 person-years } & $8 \cdot 2$ & 0 & 0 & 15.9 & 3.7 & 0 & $\begin{array}{r}(2 \cdot 01) \\
11 \cdot 6\end{array}$ & $\begin{array}{r}(2 \cdot 5) \\
1.9\end{array}$ & $\begin{array}{c}(1 \cdot 54) \\
0\end{array}$ \\
\hline & \multicolumn{3}{|c|}{$3 \cdot 3$} & \multicolumn{3}{|c|}{$5 \cdot 9$} & \multicolumn{3}{|c|}{$4 \cdot 7$} \\
\hline
\end{tabular}

"Expected" relapses are shown in brackets for combined groups; $\chi^{2}$ test shows $\mathrm{P}$ between 0.02 and 0.05 .

TABLE VII

RELAPSES AMONG PATIENTS CLOSING CAVITIES UNDER CHEMOTHERAPY AND SUBSEQUENT FATE

\begin{tabular}{|c|c|c|c|c|c|c|c|c|c|c|}
\hline & \multirow[b]{2}{*}{ Case } & \multirow{2}{*}{$\begin{array}{l}\text { Extent } \\
\text { of } \\
\text { Disease }\end{array}$} & \multirow{2}{*}{$\begin{array}{l}\text { Duration of } \\
\text { Chemotherapy } \\
\text { after Closure } \\
\text { in Months }\end{array}$} & \multirow{2}{*}{$\begin{array}{c}\text { Other } \\
\text { Measures }\end{array}$} & \multicolumn{2}{|c|}{ Form of Relapse } & \multirow{2}{*}{$\begin{array}{c}\text { Subsequent } \\
\text { Measures } \\
\text { Other than } \\
\text { Chemotherapy }\end{array}$} & \multicolumn{3}{|c|}{ Present Condition } \\
\hline & & & & & Radiological & Sputum & & Cavity & $\begin{array}{l}\text { Drug } \\
\text { Status }\end{array}$ & $\begin{array}{l}\text { Work } \\
\text { Status }\end{array}$ \\
\hline \multirow{4}{*}{$\begin{array}{l}\text { Relapses } \\
\text { occurring } \\
\text { during } \\
\text { period of } \\
\text { study }\end{array}$} & W.P. & $\begin{array}{l}\text { M.A. } \\
\text { M.A. }\end{array}$ & $3+$ & $\begin{array}{c}\text { Nil } \\
,,\end{array}$ & $\begin{array}{l}\text { Cavity reopened } \\
\text { Cavity reopened } \\
\quad+\text { spread }\end{array}$ & $\begin{array}{l}\text { - ve } \\
+ \text { ve }\end{array}$ & $\begin{array}{c}\text { Nil } \\
,\end{array}$ & $\begin{array}{c}\text { Closed } \\
,,\end{array}$ & $\begin{array}{c}\text { Continuing } \\
\text {, }\end{array}$ & $\begin{array}{c}\text { Working } \\
\quad,\end{array}$ \\
\hline & J.F. & $\begin{array}{l}\text { M.A. } \\
\text { F.A. }\end{array}$ & $\begin{array}{l}2+ \\
2+\end{array}$ & P.P. & ," , & $\begin{array}{l}\text { +ve } \\
\text { +ve }\end{array}$ & $\begin{array}{l}\text { P.P. } \\
\text { Thoracoplasty } \\
\text { after cavity } \\
\text { closure }\end{array}$ & ", & $\begin{array}{l}\text { Stopped } \\
,,\end{array}$ & ", \\
\hline & D.B. & F.A. & Nil & Nil & $\begin{array}{l}\text { Spread in area of } \\
\text { former cavity }\end{array}$ & $+\mathrm{ve}$ & Thoracoplasty & , & ,, & , \\
\hline & A.H. & Min. & $3+$ & $\begin{array}{c}\text { Thoraco- } \\
\text { plasty }\end{array}$ & $\begin{array}{l}\text { Spread under } \\
\text { thoracoplasty }\end{array}$ & $+\mathrm{ve}$ & Sub judice & , & Continuing & $\begin{array}{l}\text { Not } \\
\text { working }\end{array}$ \\
\hline
\end{tabular}


TABLE VIII

EXPERIENCE AS REGARDS CAVITY CLOSURE OF 115 PATIENTS WITH CAVITIES RECEIVING CHEMOTHERAPY

\begin{tabular}{|c|c|c|c|c|c|c|c|}
\hline $\begin{array}{c}\text { Period after } \\
\text { Drugs Begun } \\
\text { in Months } \\
\text { X }\end{array}$ & $\begin{array}{c}\text { Number } \\
\text { Entering } \\
\text { Period } \\
\text { Ox }\end{array}$ & $\begin{array}{c}\text { Number } \\
\text { Closing } \\
\text { Cavities } \\
\text { Cx }\end{array}$ & $\begin{array}{c}\text { Withdrawn } \\
\text { from } \\
\text { Observation } \\
\text { Wx }\end{array}$ & $\begin{array}{c}\text { Persons } \\
\text { Exposed to } \\
\text { Cavity } \\
\text { Closure } \\
O x-\frac{W x}{2}\end{array}$ & 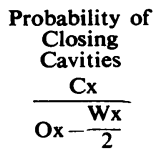 & $\begin{array}{l}\text { Probability of } \\
\text { Not Closing } \\
\text { Cavities }\end{array}$ & $\begin{array}{l}\text { Expected } \\
\text { Percentage of } \\
\text { Patients with } \\
\text { Unclosed Cavities } \\
\text { at Beginning } \\
\text { of Period }\end{array}$ \\
\hline $\begin{array}{l}0- \\
1- \\
2- \\
3- \\
4- \\
5- \\
6- \\
7- \\
8- \\
9-\end{array}$ & $\begin{array}{r}115 \\
108 \\
92 \\
72 \\
52 \\
35 \\
27 \\
16 \\
9 \\
4\end{array}$ & $\begin{array}{r}2 \\
12 \\
9 \\
14 \\
7 \\
2 \\
5 \\
6 \\
1 \\
0\end{array}$ & $\begin{array}{r}5 \\
4 \\
11 \\
6 \\
10 \\
6 \\
6 \\
1 \\
4 \\
4 \\
0\end{array}$ & $\begin{array}{c}112 \cdot 5 \\
106 \\
86 \cdot 5 \\
69 \\
47 \\
32 \\
24 \\
15 \cdot 5 \\
7 \\
4\end{array}$ & $\begin{array}{l}0.0178 \\
0 \cdot 1132 \\
0 \cdot 1040 \\
0 \cdot 2029 \\
0 \cdot 1499 \\
0.0625 \\
0 \cdot 2083 \\
0.3871 \\
0 \cdot 1427 \\
0\end{array}$ & $\begin{array}{l}0.9822 \\
0.8868 \\
0.8960 \\
0.7971 \\
0.8501 \\
0.9375 \\
0.7917 \\
0.6129 \\
0.8573 \\
1.0\end{array}$ & $\begin{array}{r}100 \\
98 \\
87 \\
78 \\
62 \\
53 \\
50 \\
39 \\
24 \\
21\end{array}$ \\
\hline
\end{tabular}

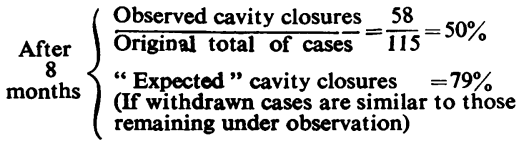

alone. The estimate of $79 \%$ may therefore be high. It may be stated that the true frequency of cavity closure on chemotherapy lies between $50 \%$ and $79 \%$, and it is probably nearer the latter figure.

\section{Discussion}

Medical management is frequently governed by clinical impressions and traditions. This is as true in the field of tuberculosis as it is in other medical branches. While clinical impressions may form the basis of sound practice, it is desirable that they should, if possible, be submitted to reasonably scientific proof, no matter how well established they appear to be.

Cavitation in pulmonary tuberculosis has long been regarded as a feature of grave import. There is ample justification in the literature for dreading the unclosed cavity, and, during recent decades, increasing emphasis in treatment has been placed on the closure or excision of the cavity. It is possible that with the skilled use of drugs available now or in the future sterilization of cavities or indefinite suppression of bacterial activity may be practicable, in part robbing the cavity of its terrors and perhaps even modifying the present emphasis on its eradication. At the moment, however, the cavity remains a principal objective for our therapeutic efforts.

A conservative régime in the pre-chemotherapy era achieved closure of cavities in a small proportion of cases. May (1927) had 27 cases out of 457 in which cavities closed on bed rest alone; Barát (1929) observed a 9.6\% closure rate from 319 cases; Grenville-Nathers (1947) noted closure of cavities in 37 out of 72 patients with bed rest as the sole form of treatment, the average time being 10 months. The subsequent history of these cases is not known.

It is generally recognized that closure of tuberculous cavities is frequently obtained with the use of modern drugs without adjuvant treatment other than rest. The frequency was estimated in the present study to lie between $50 \%$ and $79 \%$ and probably nearer the latter figure. The organisms of all patients were sensitive to at least two of the commonly used antituberculous drugs-streptomycin, sodium para-aminosalicylate (P.A.S.), and isoniazid. Drugs were always used in combination - usually streptomycin and P.A.S., streptomycin and isoniazid, or P.A.S. and isoniazid, both drugs being given daily, although in the earlier part of this study streptomycin was sometimes given intermittently in combination with P.A.S. or isoniazid before evidence of increased risk of bacterial resistance with such intermittent régimes was published (Medical Research Council, 1953, 1955; Scadding, 1955a).

We have found relatively few comparable studies in the literature indicating the frequency. with which $N$ cavities close with chemotherapy as the sole defini- N tive treatment. Tempel (1953), using streptomycin and P.A.S. in combination, or streptomycin and isoniazid, found that 20 to $30 \%$ of cavities closed $\stackrel{\odot}{\overparen{D}}$

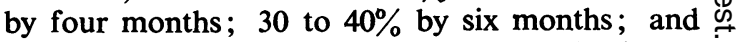
60 to $70 \%$ by eight months. Edwards (1953) observed cavity closure in $30 \%$ of his patients receiving streptomycin and P.A.S. for 90 days. Using the combination pyrazinamide and isoniazid, Muschenheim, McDermott, McCune, Deuschle, Ormond, and Tompsett (1954) observed cavity closure in 28 out of 36 cases $(77 \%)$, all but five of 
these occurring during the first six months. Moyer and Schwartz (1954) used the same combination of drugs to treat 30 patients who had failed to improve with previous treatment, and of 28 patients with cavitation cavities had closed in eight by the end of four months; the results in a few patients treated for 12 months were better.

Tempel (1953) mentioned that where single agents had been used cavity closures did not exceed 4 to $10 \%$ at four months. Deuschle and others (1954), also using one drug (isoniazid), observed cavity closure in 15 out of 44 cases $(34.1 \%)$ with cavitary disease. Charles (1955) treated over 50 patients with P.A.S. alone-the drug being given by the intravenous route-and noted that cavities closed in one-third of the cases; he mentioned that Paraf and Fouquet (1952), who used the same treatment, had noted complete disappearance of cavities in $30 \%$ of their cases. Confirmation of these results by Jaccard (1954) was reported.

Other authors have discussed not the frequency of cavity closure with chemotherapy but the mechanisms which are believed to be involved (Loesch, 1944; Silverman, Klopstock, and Gibbons, 1952; Altman and Ornstein, 1954; Pagel and Simmonds, 1942).

Some observers have been reluctant to accept that cavity closure achieved by drugs could be permanent in more than a small proportion of cases unless the additional security of surgery or collapse treatment was provided. Jones (1953) expressed suspicion of a closed cavity and thought resection should follow. Keers (1955) preferred to regard the " blocked" cavity as unstable and was not prepared to leave it alone save in the presence of some very definite surgical contraindication. Scadding (1954) suggested that the relapse rate might be high after stopping treatment in the case of cavities closed by chemotherapy if no additional measures were adopted.

One of the objects of the present study was to examine the belief that the closure of a cavity by chemotherapy alone is insecure. The results did in fact show a lower relapse rate where " protective" surgery was employed after cavity closure, but the figures are small and inconclusive. Of more importance is the comparatively modest relapse rate experienced to date by the group treated on conservative lines without surgery or collapse. It is a moot point whether, in the face of a relapse rate of such relatively small dimensions, the additional possible advantages of surgery and collapse justify the expenditure of surgical skill and the risk to the patient attendant on any operative procedure. Admittedly, however, the observation period has been short, and without several years' further follow-up any conclusions must be tentative.

The Relation of Duration of Chemotherapy AND RELAPSE.- The current tendency among clinicians is to use chemotherapy for longer periods. Evidence has been presented in this study which supports the soundness of this trend. No relapses have been observed in this series where chemotherapy had been continued for more than six months after the first radiograph showing no evidence of a cavity, while there has been an appreciable relapse rate $(11.6 \%$ per year) among the patients receiving chemotherapy for less than four months. There was a statistically significant relationship between the duration of chemotherapy and the frequency of relapse. It appears likely that the relapse rate will be influenced by the duration of drug treatment even where collapse therapy or resection is also employed. Resection does not imply the removal of all tuberculous foci. Lesions remain which may be too small to be seen radiologically but which nevertheless form the seeds of future relapse. Adequate use of chemotherapy should minimize the likelihood of such an event.

Our scrutiny of the records of the patients in the present study showed that four had undergone the cycle of cavity closure on chemotherapy with subsequent relapse before the period of study. In all four cases the duration of chemotherapy after this earlier cavity closure had been short, the longest period being four months.

Bacteriological examination of resected solid foci shows a relationship between the duration of chemotherapy and the likelihood of culturing bacilli from such lesions (Turnbull, Stewart, and Macgregor, 1955). Other workers have reported the failure to culture tubercle bacilli from caseous foci resected after long continued chemotherapy, even though acid-fast rods were seen on direct examination (D'Esopo, Ryan, and Medlar, 1951; D'Esopo, Bernstein, Decker, Raleigh, and Steenken, 1953; Steele, 1953; American Trudeau Society, 1953).

In comparing therapeutic régimes, one must take into consideration not only their effectiveness and freedom from risk to the patient but the period elapsing before the patient can resume his place as a useful member of the community. Many of the patients in this series have returned to work (or normal household duties) while still receiving drug therapy.

Of the 88 conservatively treated patients who have not relapsed, 84 had returned to work by the time of the last observation; of the 44 cases in the 
surgical group who have remained well, 43 had returned to work.

In the conservative group the median period elapsing between the start of treatment and return to work was 399 days, while the mean was 410 days. Corresponding figures for the surgical group were a median period of 420 days (432 for major surgical and 410 for those receiving minor collapse measures) and a mean period of 493 days (501 days for major cases and $\mathbf{4 8 2}$ for minor cases).

The decision to use major surgical measures after cavity closure is frequently governed by the size of any solid foci remaining. Such a trend was evident in the present study. There is a widely held clinical impression that a large solid focus is more dangerous than a small one. Bernou and Tricoire (1949), who followed up 147 patients whose cavities had closed with no other treatment than bed rest, did not mention the frequency of the occurrence, but analysed the relapses with relation to the residual focus. Of their cases $7.1 \%$ relapsed over a period varying from approximately one to five years, and, of these, $29.6 \%$ had residual foci of over $1 \mathrm{~cm}$.; $6.5 \%$ had foci of $3 \mathrm{~mm}$. to $10 \mathrm{~mm}$. and $1 \%$ had foci less than $3 \mathrm{~mm}$. Scadding (1955b), in considering the problem of the residual caseous focus, referred to the custom of adopting some arbitrary measure of size as warranting resection. Bickford, Edwards, Esplen, Gifford, and Thomas (1952) advised excision of foci greater than $1 \mathrm{~cm}$. in diameter persisting longer than a year. Keers (1955) considers that surgery is desirable for all blocked cavities and for solid foci of 1.5 to $2 \mathrm{~cm}$. diameter. Cleland (1954) stated that lumps greater than $2 \mathrm{~cm}$. should be removed.

Mitchell (1953), who followed 39 cases over four to 22 years, found about one chance in four of progression of disease when pulmonary tuberculosis was characterized by one or more solitary dense circumscribed foci and had been treated without chemotherapy, resection, or collapse. There has been no unanimity, however, among those writers who have studied the subsequent experience of patients with solid lung foci. Macleod and Tait Smith (1952) quote the experience of different workers and express the view that the small focus is not necessarily benign nor is the larger one an inevitable source of spread.

In our own study we were unable to demonstrate any clear relationship between size of residual foci after cavity closure and likelihood of relapse. Further evidence on this point is desirable.

In studying the relationship between relapse and size of residual foci, we omitted cases submitted to resection. This step is perhaps open to criticism.
We were faced with the problem of deciding whether the resection cases should be allocated to the three groups with residual foci of different size, according to the radiological appearance pre-operatively; whether they should be allocated to the group with small residual foci as the operative procedure entailed the removal of the larger foci; or whether they should be omitted from the analysis. We elected to follow the last course. This dilemma throws into relief the type of problem so frequently encountered in retrospective studies. Fven the strictest criteria and strictest honesty may be insufficient to guard against the possibility of bias. If ethically justified, a controlled trial with a random allocation of patients is preferable. We believe on the basis of the present study that there is justification for such a trial and one is at present under way.

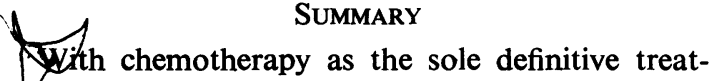 nent, closure of tuberculous lung cavities may be expected in 50 to $79 \%$ of cases.}

Among 138 cases in which cavities were closed under chemotherapy, six relapses were observed. The most important factor in determining the likelihood of relapse appeared to be the duration of chemotherapy after cavity closure.

No definite relationship between size of residual solid foci and the incidence of relapse could be demonstrated.

One of the authors (D. T. Kay) is a Royal Victoria Hospital Tuberculosis Trust Research Fellow. Our thanks are due to the Trust also for the secretarial assistance of N.rs. Honywill.

We are grateful to Professor J. W. Crofton for allowing us to study the records of patients who were under his care at Southfield Hospital. The remaining patients were treated at the Royal Victoria Hospital and East Fortune Hospital.

\section{REFERENCES}

Altman, V., and Ornstein, G. G. (1954). Quart. Bull. Sea View Hosp., 15, 1

American Trudeau Society (1953). Amer. Rev. Tuberc., 68, 477.

Barát, I. (1929). Beitr. Klin. Tuberk., 72, 668.

Bernou, A., and Tricoire, J. (1949). Rev. Tuberc. (Paris), 5 ser., 13,778 .

Bickford, B. J., Edwards, F. R., Esplen, J. R., Gifford, J. G., and Thomas, O. F. (1952). Thorax, 7, 310.

Charles, F. (1955). Tubercle (Lond.), 36, 40.

Cleland, W. P. (1954). Postgrad. med. J., 30, 305.

D'Esopo, N. D., Ryan, B. J., and Medlar, E. M. (1951). Transactions, 10th Conference on Chemotherapy of Tuberculosis, p. 78 Veterans Administration, Washington.

- Bernstein, S., Decker, A. M., Raleigh, J. W., and Steenken, W (1953). Transictions, 12th Conference on Cnonotherapy of Tuberculosis, p. 229. Veterans Adninistration, Washington.

Deuschle, K., Ormond, L., Elmendorf, D., Jr., Mascienheim, C., and McDermott, W. (1954). Amer. Rev. Tuberc., 7v, 228.

Edwards, G. F. (1953). Tubercle (Lond.), 34, 42.

Grenville-Mathers, R. (1947). Ibid., 28, 139. 
Jaccard, G. (1954). Praxis, 43, 422.

Jone s, J. C. (1953). Panel Discussion. Amer. Rev. Tuberc., 68, 830.

Keers, R. Y. (1955). Brit. J. Tuberc., 49, 198.

Loesch, J. (1944). Amer. Rev. Tuberc.. 50, 500.

Macleod, W. M., and Smith, A. Tait (1952). Thorax, 7, 334.

May, W. (1927). Beitr. Klin. Tuberk., 67, 191.

Medical Research Council (1953). Lancet, 2, 217.

- - (1955). Brit. med. J., 1, 435

Mitchell, R. S. (1953). Ann. intern. Med., 39, 471.

Moyer, R. E., and Schwartz, W. S. (1954). Trans. 13th Conference on the Chemotherapy of Tuberculosis, p. 166. Veterans Administration, Washington.

Muschenheim, C., McDermott, W., McCune, R., Deuschle, K. Ormond, L., and Tompsett, R. (1954). Amer. Rev. Tuberc., 70, 743
Pagel, W., and Simmonds, F. A. H. (1942). Amer. J. med. Sci., 203 177.

Paraf, J., and Fouquet, J. (1952). Le traitement de la tuberculose par l'acide para-aminosalicylique. Masson, Paris.

Scadding, F. H. (1954). Postgrad. med. J., 30, 294.

Scadding, J. G. (1955a). Lancet, 2, 99.

- (1955b). Ibid., 2, 49.

Silverman, G., Klopstock, R ., and Gibbons, G. (1952). Dis. Chest, 21, 86 .

Steele, J. D. (1953). Trans. 12th Conference on Chemotherapy of Tuberculosis, p. 209. Veterans Administration, Washington.

Tempel, C. (1953). Panel Discussion. American Trudeau Society. Amer. Rev. Tuberc., 68, 830.

Turnbull, F. W. A., Stewart, S. M., and Macgregor, A. R. (1955). Unpublished. 